\title{
The Government's Power and Democracy Participation to Eradicating Inequalities in Local
}

\author{
Idil Akbar' ${ }^{1}$, Elly Nurlia $^{2}$
}

${ }^{1}$ Department of Government Science, Faculty of Social and Political Science, University of Padjadjaran, Jl. Raya BandungSumedang Km. 21, Jatinangor, Sumedang, Jawa Barat 40132, Indonesia

${ }^{2}$ Department of Government Science, Faculty of Social and Political Science, University of Mathla'ul Anwar, Jl. Raya

Labuan Km. 23, Cikaliung, Saketi, Kec. Pandeglang, Banten 42273, Indonesia

\begin{abstract}
One of path to implement of democracy's values to eradicating inequalities is opened widely for public participation. As democracy's value for government is how the government must present democracy participate on its people. The government must create democracy participate in every level, including in local. This part will become differentiator how is the government's run. This article purposed to description and discussion how is the government's power and democracy participate frequent contradiction complicated, full dynamics, and conflict. Despite of government has given ample opportunities for peoples, but sometimes peoples must face the policies which uncompromised with this participation. This article based on research with qualitative descriptive method and data collected by literature. Resulted that Undang-Undang (Indonesian laws) has given the amble opportunities for peoples to participate in local politics and governance. The laws also giving generous to peoples to run participation based on local's values. Nevertheless, the freedom to participate frequent confronted with government interest which dominated by elite. Thus, in fact the local's peoples truly had efforts to participate in local politics and governance actively must face with government's power dominantly and determinately.
\end{abstract}

Keywords: The Government's Power; Democracy Participative; Equality Local Democracy, Governance

\section{Introduction}

"Citizen Participation is at the heart of democracy. Indeed, democracy is unthinkable without the ability of citizens to participate freely in the governing process."

-- Verba et al. 1995

Statement of Sidney Verba above describes how the importance of public participation or peoples in democracy, or in other words, this explain that participation is the substance of the most crucial in democracy. Therefore, participation was placed as the main conditions in building democracy. As one of the important values of democracy, participation aimed to build active engagement in governance and development. Cause, public engagement made a government can be more meaningful and have high values, especially in the framework of making democratic governance and participatory.

In deliberative perspective, participation also related with equality. Both important in the government run. As Young or Emmanuel made the participation and equalities as two important aspects in building deliberative of democracy [1]. The importance aspects of participation and equality have become guidance assessed the reign of running democratically. Or in other words, the value of participatory democracy and equality in government is very depending on how far the government and stakeholders power invites public participation in it, open space for public involvement and integrate the various problems in the settlement in a participative manner. This is where the importance of the true meaning of substantive democracy, where the public as the owner of the power in the government.

But in many cases, the public is not fully can participate caused by the existence of various purposes related to the interests of the ruling government. So that even though there is a desire to participate in line with efforts to build democratisation in government, people still find obstacles in engaging in public affairs.

In addition, some of the following factors also become barriers or obstacles in encouraging citizen participation in the government. The citizen participation is faced with various problems at both the state and local level, among others: first, 
participation in the process of local planning generally started very late; second, citizen participation that really very little especially on issues such as the growth and development of the city; third, when the participation is really desired too few people who organized; fourth, Government and local government mostly avoid citizen participation, with make decisions in secret; and fifth, in general, communities do not have a good resources In terms of time, expertise or space to make their aspirations heard effectively [2].

This is also often become the main issue, especially in reconstruct participatory democracy in the community. Especially in the era of regional autonomy is widely give the opportunity for local communities to improve their own life according to the initiative of each. Of course, autonomy policy in line with the principle of democracy where democracy entrusted his existence broad freedom to the community. The freedom of speech, the freedom to get proper livelihoods, freedom gain access to education and etc. is the target of democracy [3].

Report of public participation in Europe; an international perspective stated that there are three important challenges for participation, those are (1) the challenge of cost-including costs of time, money and potentially political costs if participation is poorly handled; (2) the challenge of complexitydiscerning which participatory practices are suited to the scale of a problem and the technicalities involved; and (3) the challenge of representativeness - involving a 'mini-public' that mirrors the broader society and adequately considers the interests of those with most at stake [4]. The government therefore become the main tool for society assessed participation effected and make sure participation run well.

\section{Methodology}

This research uses qualitative research methods with an approach that is both naturalistic and descriptive, so that the emphasis is not on a base measurement (statistics), but more on describing the actual, factual, natural, holistic, and about how the government's power and democracy participation can eradicate inequalities in local. The data collected through the study of literature by reviewing various information comes from documents, mass media, journals, etc. Then data analysis is done through a review of the data, interpreting and make conclusion.

\section{Discussion}

Participation is the right of every person. The right to participation has consequences on support for participation by citizens and other people who live within the boundaries of the state. It means working for the obligation of the state at national, intermediate (provincial, district, county, etc.) and local levels to recognise the right to participation for all, as well as to ensure access to information by all individuals [5].

At the local level governments need to understand the development of the society in order to fulfil the obligation of the government at the same time fulfil the rights of the community. Communities have the right to know what the government and how the government is working. Those who have been paying taxes need to know how the money is used. The importance of participation is so that everyone can engage in government, because if this is not the case then the government can act with impunity and stifle the own decisions without listening to the opinion of the community. So that can lead to the abuse power. The Constitution requires the importance of participation and ease on every person to engage in the government [6].

The idea of representative democracy and participatory democracy is often compared. In contextual learning both actually have the difference. Representative democracy is the way to select the members of the House of Representatives by a trusted citizens as representatives of the people and on duty in decision making involving the interests of the people. Participatory democracy more refers to the process where inside the dialog occurs, communication and debate between the community and the government [7].

Thus, the participatory democracy is basically a process where the public could make aspirations, discussion and debate about a problem, do dialog with stakeholders, that is local government so that the community can understand the problems that occur as well as to participate in the settlement of the problem.

Many community and public leaders as well as many public officials realize that public participation is important in an environment where the citizens have a diminished trust in government and are demanding more accountability from public officials [8]. This explains that the public participation coherently with the belief that built the public against its rulers. The public trust to government is very depending on how the political elite build good leadership in the government.

The interaction between citizens with the government that includes involving various social actors who have various desires and interests are part of the participation of citizens. Even though the people became an important point in the public participation, but the entire process, agenda and procedure in the participation is usually determined by the government. So this is often a barrier for citizens to participate [9].

Does every citizen can participate and how big the opportunity to participate can be done? Basically, opportunities for participation depend on the existence of a democratic political environment as well as on legislation that stipulates a sound relationship between the state and its people. 
Therefore, democratic governance become the main requirements for the creation of citizen participation. While a democratic government can only occur if the authority is obtained and run in a way that is not democratic.

Similiar with government, understanding about the participation in the logic of development also need to narrowly defined; first, provide stimulation in increase the efficiency and effectiveness of development and a large proportion of the community and in the framework of promoting the process of democratisation and empowerment [10].

Second, participation also can be considered as an instrument (means) and purpose (ends) which each other an apparent contradiction with one another. Third, participation referred to as elite capture where political elites, actors and public figures in the political reality is always in contact with the program participation, but in fact thus far from participatory practices.

In the instrumental perspective, the relationship between the community as the objective of the program and policy makers or aid agencies relatively not happen. In other words, there is no interaction between the two parties so that the design of the program and development policy are made more or even fully in the hands of the elite [11]. This is typology of public participation base on type of participation and representative level:

Table I. Typology Of Public Participation

\begin{tabular}{|c|c|c|}
\hline Type of participation & \multicolumn{2}{|c|}{ Level of representative } \\
\hline & Tight & Wide \\
\hline False & $\begin{array}{l}\text { Decision: less transparent } \\
\text { decision made by a public } \\
\text { official } \\
\text { Participation: symbolic, } \\
\text { only a handful of people } \\
\text { involved }\end{array}$ & $\begin{array}{l}\text { Decision: made by public } \\
\text { officials } \\
\text { Participation: symbolic, } \\
\text { although involving various } \\
\text { groups in society }\end{array}$ \\
\hline Partial & $\begin{array}{l}\text { Decision: made by a group } \\
\text { of elite of the government to } \\
\text { consider input from interest } \\
\text { groups that limited } \\
\text { Participation: } \\
\text { involves interest groups that } \\
\text { have the influence, while some } \\
\text { people do not have the } \\
\text { opportunity to completely }\end{array}$ & $\begin{array}{l}\text { Decision: made by } \\
\text { government officials with } \\
\text { very little influence from the } \\
\text { community participation } \\
\text { Participation: involving } \\
\text { various interest groups but the } \\
\text { opportunity to participate } \\
\text { provided in the session is very } \\
\text { limited. }\end{array}$ \\
\hline Full & $\begin{array}{l}\text { Decision: made by } \\
\text { government officials and } \\
\text { interest groups who elected } \\
\text { Participation: involve } \\
\text { interest groups that have the } \\
\text { influence, but most of the } \\
\text { citizens still lack opportunity }\end{array}$ & $\begin{array}{l}\text { Decision: made by } \\
\text { government officials with a } \\
\text { very strong influence from the } \\
\text { community participation } \\
\text { Participation: the wider } \\
\text { community involved in } \\
\text { discussions with the } \\
\text { government of intensive } \\
\text { enough }\end{array}$ \\
\hline
\end{tabular}

Source: Erman I. Rahman. p.4

According to the European Institute for Public Participation (EIPP), there are three main requirements for successful public participation: (1) a clearly defined constitutional framework for public participation. Only through an explicit, shared understanding between politicians and citizens can confidence be developed and public participation realise its democratising potential; (2) a systematic approach to public participation methods to help organisers of public participation processes choose the most suitable and effective methods; and (3) rigorous and challenging evaluation of public participation in practice to develop a culture of learning about participation and advance the systematisation of participatory methods [12].

Therefore, people need to be encouraged to participate in continueosly in local government. The citizens participation basically has advantages as socially, politically and other benefits. 


\section{Conclusion}

In accordance with the concept of participatory democracy that more advancing process of communication and dialog within the government and the local government should start to be more open to demands of the community to participate in government and development. The policy that made the government should start involving the community in it openly and accountability. Even though the implementation is often created conflicts of interest, but the involvement of the community still must take precedence. This is a distinguishing whether a government has been running in a democratic or not, with measure on how far the public participation opened as wide as possible in the implementation of local government.

\section{References}

1. C. Farrelly, "Contemporary Political Theory", SAGE Publications, London (2004).

2. I. Indratno, et. al., "Literature Study of Democracy Participation: an article", Retrieved

from https://datastudi.files.wordpress.com/ on October 12, 2017 (2011).

3. H. Kusmanto, "Citizen Participation in Political Democratic.” Jurnal Ilmu Pemerintahan dan Sosial Politik UMA, 2(1), pp 78-90 (2014).

4. Brenton Holmes. "Citizens' engagement in policymaking and the design of public services", Research Paper No.1, 2011-12, Parliament of Australia, Department of Parliamentary Services, p.6 (2011).

5. SIDA (A summary). "Participation in Democratic Governance, A summary of the four methods reports", Digging Deeper p.8 (2003).
6.

, "Democracy, Government and Public Participation", Retrieved from http://paralegaladvice.org.za on October 12, 2017(2016).

$7 . \quad$. "Participatory Democracy \& Service Delivery in the Context of Local Government". Address by the MEC: Local Government and Housing to the Public Participation Conference", Retrieved from https://www.westerncape.gov.za on October 12, 2017 (2005).

8. P. D. Gibson, D. P. Lacy and M. J. Dougherty. "Improving Performance and Accountability in Local Government with Citizen Participation". The Innovation Journal: The Public Sector Innovation Journal, 10 (1) pp. 1-12 (2005).

9. J. Gaventa and C. Valderrama, "Participation, Citizenship and Local Governance": An Article for workshop on strengthening participation in local governance, Institute of Development Studies (2005).

10. B. Cooke and U. Kothari, "Participation: The New Tyranny?", Zed Books, London (2002).

11. E. I. Rahman, Retrieved from http://repository.ung.ac.id on October 12, 2017.

12. European Institute for Public Participation, "Public participation in Europe: an international perspective", p. 4, Retrieved from http://www.participationinstitute.org/ on October 12, 2017(2009). 